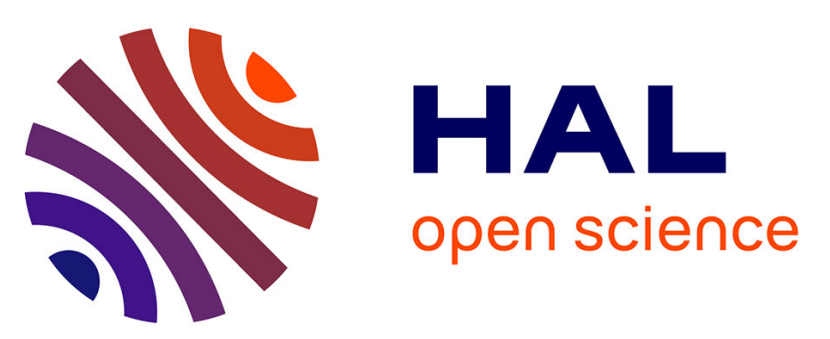

\title{
Chemical vapor infiltration of photocatalytically active TiO2 thin films on glass microfibers
}

Christos Sarantopoulos, Alain Gleizes, Francis Maury

\section{To cite this version:}

Christos Sarantopoulos, Alain Gleizes, Francis Maury. Chemical vapor infiltration of photocatalytically active $\mathrm{TiO} 2$ thin films on glass microfibers. Surface and Coatings Technology, 2007, vol. 201, pp. 9354-9358. 10.1016/j.surfcoat.2007.04.073 . hal-00806205

\section{HAL Id: hal-00806205 \\ https://hal.science/hal-00806205}

Submitted on 29 Mar 2013

HAL is a multi-disciplinary open access archive for the deposit and dissemination of scientific research documents, whether they are published or not. The documents may come from teaching and research institutions in France or abroad, or from public or private research centers.
L'archive ouverte pluridisciplinaire HAL, est destinée au dépôt et à la diffusion de documents scientifiques de niveau recherche, publiés ou non, émanant des établissements d'enseignement et de recherche français ou étrangers, des laboratoires publics ou privés. 


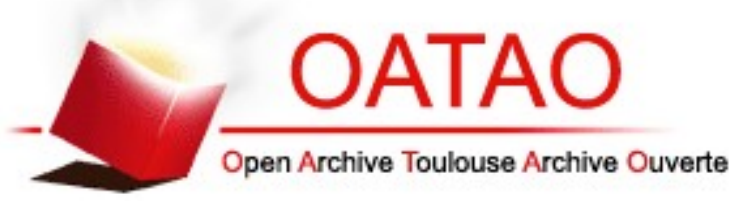

\section{Open Archive Toulouse Archive Ouverte (OATAO)}

OATAO is an open access repository that collects the work of Toulouse researchers and makes it freely available over the web where possible.

This is an author-deposited version published in: http://oatao.univ-toulouse.fr/ Eprints ID : 2443

To link to this article :

URL : http://dx.doi.org/10.1016/j.surfcoat.2007.04.073

To cite this version : Sarantopoulos, Christos and Gleizes, Alain and Maury, Francis ( 2007) Chemical vapor infiltration of photocatalytically active TiO2 thin films on glass microfibers. Surface and Coatings Technology, vol. $201\left(\mathrm{n}^{\circ} 22\right.$ 23). pp. 9354-9358. ISSN 0257-8972

Any correspondence concerning this service should be sent to the repository administrator:staff-oatao@inp-toulouse.fr 


\title{
Chemical vapor infiltration of photocatalytically active $\mathrm{TiO}_{2}$ thin films on glass microfibers
}

\author{
Christos Sarantopoulos*, Alain N. Gleizes, Francis Maury \\ CIRIMAT, CNRS/INPT/UPS, ENSIACET, 118 Route de Narbonne, 31077 Toulouse cedex 4, France
}

\begin{abstract}
Due to the high diffusivity of the chemical species, chemical vapor infiltration (CVI) is a suitable process for the conformal coverage of objects with large dimensions and complex shape geometry. Its large scale capacity and high reproducibility have made the technique favorable for the deposition of non-oxide ceramics. There are few works on other materials and metal-organic compounds are rarely used as molecular precursors. In this study we focus on the deposition of anatase thin films on substrates with large surface area (microfibers) for photocatalytic air treatment systems. Titanium tetra-isopropoxide (TTIP) was used as precursor without additional oxygen source. Using low mole fractions $\left(26-124 \times 10^{-5}\right)$ and low deposition temperatures $\left(300-400{ }^{\circ} \mathrm{C}\right)$, a relatively good thickness uniformity was obtained along the reactor axis. Infiltration experiments were achieved in this temperature range and under 1 Torr for high TTIP diffusivity (110-146 $\left.\mathrm{cm}^{2} \mathrm{~s}^{-1}\right)$ and low initial Thiele modulus $(0.11-0.13)$ values. Photocatalytic activity of $\mathrm{TiO}_{2}$ coated glass microfiber samples depends on the film morphology, average thickness and infiltration efficiency. It is shown that this later parameter plays a major role due to the increase of active surface area.
\end{abstract}

Keywords: CVI; Infiltration; Microfibers; Titanium dioxide; Anatase; Photocatalysis

\section{Introduction}

Chemical vapor infiltration (CVI) is an efficient process for producing ceramic-matrix composites materials such as $\mathrm{SiC}[1]$ and $\mathrm{TiC}[2]$, pyro-C [3] or refractory metal-matrix such as Re [4]. In particular, isothermal isobaric CVI is a well studied process applied in industrial scale but it is characterized by low deposition rates and long infiltration times. For these reasons many studies were focused on theoretical and numerical modeling to optimize the densification rates [5]. To our knowledge, CVI has not been used for the growth of oxide ceramics on glass fibers. Furthermore, the use of metal-organic precursors in CVI is rare. This is generally considered challenging because of their high reactivity at rather low temperatures which complicates the control of the deposition rate. Another reason is the low diffusivity of large metal-organic molecules as titanium tetra-isopropoxide (TTIP) through porous structures. Smaller and more stable precursors as halides $\mathrm{TiCl}_{4}[2]$ or $\mathrm{ReCl}_{5}[4]$

\footnotetext{
* Corresponding author. Tel.: +335628856 66; fax: +33562885600.

E-mail address: christos.sarantopoulos@gmail.com (C. Sarantopoulos).
}

are preferred to infiltrate substrates with large dimensions. However metal-organic precursors, such as $\mathrm{Si}\left(\mathrm{C}_{2} \mathrm{H}_{5}\right)_{4}$ for instance, were successfully used [6]. Until now almost all works for immobilizing $\mathrm{TiO}_{2}$ thin films on inorganic (glass) microfibers are using the dip coating method in a solution containing titania sol and then annealing for many hours at relatively high temperatures $\left(500^{\circ} \mathrm{C}\right)$ to obtain crystallization of nanoparticles [7]. Despite important advantages (simplicity, cheap process), $\mathrm{TiO}_{2}$ films obtained by this technique can exhibit poor adhesion [8], low conformal coverage of the fibers, and their microstructure cannot be changed as conveniently as in CVD. This can be a major drawback to produce advanced supported photocatalysts.

Carrying on a research program on $\mathrm{CVD} \mathrm{TiO}_{2}$ for various applications [9-11], we were interested in studying the use of metal-organic source like TTIP in an isothermal, isobaric CVI process in order to functionalize (not to densify) with a $\mathrm{TiO}_{2}$ thin film porous substrates of complex geometry, like glass microfiber tissues. Our goal is to produce uniform $\mathrm{TiO}_{2}$ thin films featuring high specific surface area, suitable for photocatalytic air treatment systems. Glass microfiber tissue is a 
convenient support for applications in gas treatment. It offers flexibility, large surface area compared to flat substrates, glass beads or honeycomb type supports used until now for photocatalytic applications. Furthermore, it is transparent in a large domain of light spectrum including UV-A.

In the present work, we study the influence of the growth process parameters to improve the deposition uniformity, infiltration efficiency and conformal coverage through porous substrates of relatively large dimensions at the laboratory scale. Comparisons between the CVI conditions leading to the most promising microstructure and those giving the best infiltration efficiency lead us to a compromise for the preparation conditions of supported photocatalysts.

\section{Experimental}

\subsection{Films preparation}

$\mathrm{TiO}_{2}$ films were grown in an isothermal, isobaric, horizontal low pressure-CVD reactor ( $45 \mathrm{~mm}$ in diameter). Two types of substrates were used. For preliminary experiments, flat borosilicate glass and $\operatorname{Si}(100)$ wafers were used as previously reported [12]. For the infiltration runs, "E-glass" type tissue $\left(30 \mathrm{~g} \mathrm{~m}^{-2}\right)$, obtained from C.Y.S. Grp. Composites, was used as support. It is a high void medium ( $~ 90 \%$ porosity) with pore diameter of 30-100 $\mu \mathrm{m}$ generated by randomly weaved fibers (12 $\mu \mathrm{m}$ average diameter). This tissue exhibits relatively large surface area $\left(0.13 \mathrm{~m}^{2} \mathrm{~g}^{-1}\right)$. It is stable up to $800{ }^{\circ} \mathrm{C}$ and the chemical composition is: $\mathrm{SiO}_{2} 54 \%, \mathrm{Al}_{2} \mathrm{O}_{3} 15 \%, \mathrm{CaO} 17 \%$, $\mathrm{MgO} 5 \%, \mathrm{R}_{2} \mathrm{O}<0.8 \%, \mathrm{~B}_{2} \mathrm{O}_{3} 8 \%$. Prior to CVI runs, it was thermally treated at $500{ }^{\circ} \mathrm{C}$ under air stream in order to remove the dressing thin organic film. Three to eleven tissue pieces $\left(20 \times 100 \mathrm{~mm}^{2}\right)$ were stacked for infiltration experiments. They were maintained between two aluminum frames. This assembly was placed along the reactor axis $(z)$ in the isothermal zone at $16 \mathrm{~cm}$ from the entrance. Pure nitrogen $(99.9992 \%)$ was used both as a carrier gas through the TTIP bubbler and as a dilution gas $(580 \mathrm{sccm})$. The flow rates were monitored by mass flow controllers. The TTIP mole fraction $\left(\chi_{\text {TTIP }}\right)$ was controlled by the temperature of the TTIP bubbler $\left(21-60^{\circ} \mathrm{C}\right)$ and determined by the TTIP weight loss after the CVI experiment. The total pressure was maintained constant using a vacuum pump equipped with an automatic control system. The growth temperature $\left(300-600{ }^{\circ} \mathrm{C}\right)$ was measured with a thermocouple $\mathrm{K}$ plugged into the sample holder. Film thickness (or $\mathrm{TiO}_{2}$ mass) was controlled by varying the deposition time (180-300 min).

\subsection{Films characterization}

Film crystallinity was determined by X-ray diffraction (XRD; $\theta-\theta$ geometry). Microstructure, grain size and film thickness were analyzed by scanning electron microscopy (SEM) equipped with an X-ray energy dispersive spectroscopy analyzer (EDS). The thickness uniformity along the $z$ axis and the infiltration depth through stacked glass fiber tissues were studied by measuring the Ti/Si EDS intensity ratios. $\mathrm{TiO}_{2}$ film specific surface area was measured by B.E.T analysis.

\subsection{Photocatalytic test}

The photocatalytic activity of $\mathrm{TiO}_{2}$ films was evaluated from the initial decomposition rate of a dye compound in a batch reactor. Glass tissue samples $\left(20 \times 30 \times 1 \mathrm{~mm}^{3}\right.$ and $20 \times$ $100 \times 1 \mathrm{~mm}^{3}$ ) coated with $\mathrm{TiO}_{2}$ were immerged into an Orange $\mathrm{G}$ aqueous solution $\left(10^{-5} \mathrm{~mol} \mathrm{l}^{-1}\right)$. The supported photocatalyst and $25 \mathrm{~cm}^{3}$ of the dye solution were placed into a quartz vessel $\left(28.8 \mathrm{~cm}^{3}\right)$ transparent to wavelengths $>290 \mathrm{~nm}$, and irradiated at $365 \mathrm{~nm}$ with a UV-A lamp (HPLN Philips $125 \mathrm{~W}$ ) under irradiance of $1.05 \mathrm{~mW} \mathrm{~cm}{ }^{-2}$. All solutions were first agitated for $1 \mathrm{~h}$ in the dark to assure equilibrium of adsorption with the photocatalyst. The concentration was determined by measuring the absorbance of Orange $\mathrm{G}$ at $480 \mathrm{~nm}$, using a UV/Vis spectrophotometer and applying the Beer-Lambert law. Photocatalytic degradation generally follows a LangmuirHinshelwood mechanism with the rate $r$ being proportional to the relative coverage $\theta$. In case of low initial concentrations of the dye $\left(<10^{-3} \mathrm{~mol} \mathrm{l}^{-1}\right)$, the term $K \cdot C$ can be neglected with respect to 1 and the rate becomes first order,

$r=k \cdot \theta=k \cdot K \cdot C=k_{\mathrm{a}} \cdot C$

where $k$ is the true rate constant, $K$ is the adsorption constant and $k_{\mathrm{a}}$ is the apparent rate constant. The initial decomposition rate $r_{0}$ was determined for the first $30 \mathrm{~min}$ of the reaction from the slope of the gradient of the concentration $C$ of Orange $\mathrm{G}$ as a function of time.

\section{Results and discussion}

\subsection{Growth kinetics}

Homogeneous infiltration into the pores of a preform can only be achieved if the values of the initial Thiele modulus are low [5]. This means that low growth rates, high diffusivity and high precursor concentrations are required to avoid a starving reactor mode. To achieve infiltration in an isothermal, isobaric reactor configuration, very low precursor conversion rates and long deposition times have to be achieved. In general, the overall process must be controlled by surface chemical reactions involving the precursor and not by mass transport limitation of the reactive species through the pores of the preform. For evaluating the infiltration efficiency, (i) the kinetic regime, (ii) the rate constant of the overall chemical reaction, (iii) the diffusion coefficient of the reactive species and (iv) the pore geometry must be known.

In these objectives, preliminary LPCVD runs were performed to optimize the growth rate uniformity along the reactor $z$ axis on flat substrates. A relatively good uniformity was obtained at low temperatures $\left(300-400{ }^{\circ} \mathrm{C}\right)$, low TTIP mole fractions $\left(26-124 \times 10^{-5}\right)$ and high gas flow rates. For deposition on glass fiber tissues, the thickness gradient along the reactor was estimated on the external tissue (top) of the assembly. With moderate TTIP mole fractions in the range 124$500 \times 10^{-5}$, the thickness gradient is quite smooth at $300^{\circ} \mathrm{C}$ and more pronounced at $400{ }^{\circ} \mathrm{C}$ (Fig. 1). 


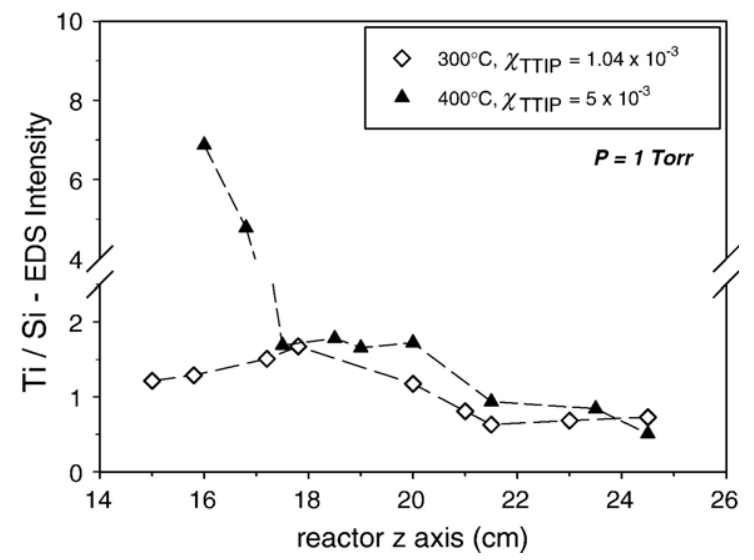

Fig. 1. Influence of the growth temperature on the axial thickness uniformity of $\mathrm{TiO}_{2}$ films deposited on the external tissue (top) of a 3 -stacked tissue assembly. The relative thickness is estimated from the Ti/Si intensity ratio of EDS signals.

Feed rate-limited deposition usually provides a rate with weak temperature dependence as observed for low TTIP mole fractions $\left(7.6 \times 10^{-5}\right)$. For higher TTIP mole fractions (26 and $103.5 \times 10^{-5}$ ), two regimes show up (Fig. 2): between 300 and $400{ }^{\circ} \mathrm{C}$ the deposition rate increases with the temperature suggesting a surface reaction-limited deposition; above $400{ }^{\circ} \mathrm{C}$ the rate depends weakly on the temperature, giving evidence for a diffusion controlled regime. Similar variations were previously reported [13].

In the kinetically controlled temperature range (300$400{ }^{\circ} \mathrm{C}$ ), the deposition rate increases linearly with the TTIP mole fraction suggesting a first order reaction. This is in good agreement with literature works [13], even if a second order reaction was reported for deposition experiments under high vacuum (no carrier gas) [14]. Because of different local growth conditions resulting from various reactor designs, discrepancies are observed for the apparent activation energy values. The value found here $\left(93 \mathrm{~kJ} \mathrm{~mol}^{-1}\right)$ is in the literature range $[9,10,15]$. The infiltration experiments were performed at

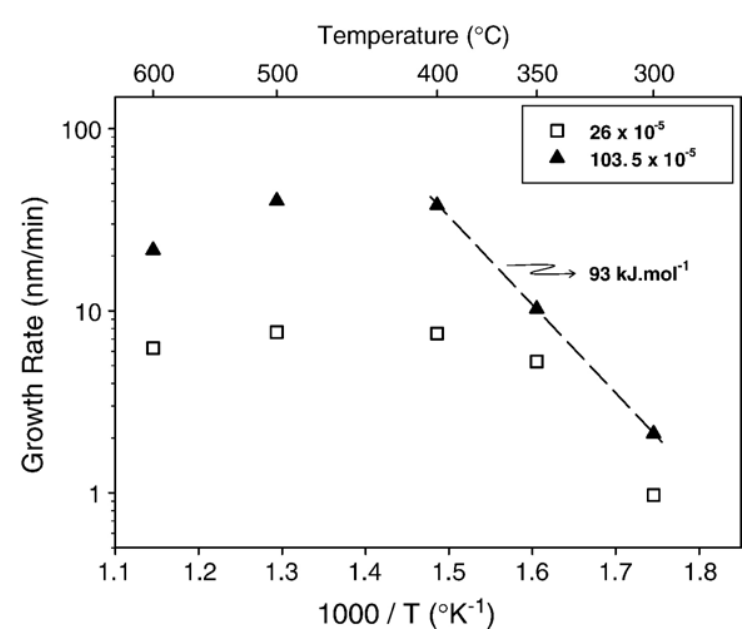

Fig. 2. Arrhenius plot for the growth rate of $\mathrm{TiO}_{2}$ on $\mathrm{Si}(100)$ substrates from TTIP $\left(P=20\right.$ Torr, $\chi_{\mathrm{TTIP}}=26 \times 10^{-5}$ and $\left.103.5 \times 10^{-5}\right)$.

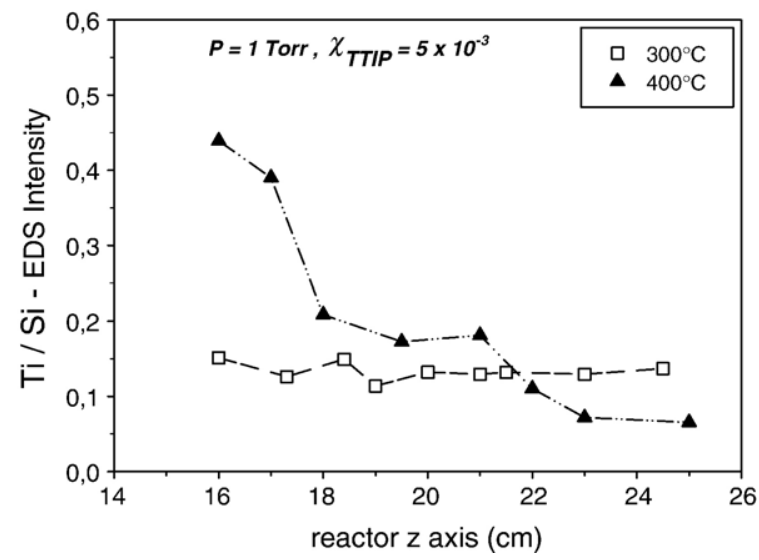

Fig. 3. Influence of the deposition temperature on the infiltration efficiency analyzed by film thickness uniformity on the middle tissue of a 3-stacked tissue assembly. The relative thickness is estimated from the $\mathrm{Ti} / \mathrm{Si}$ intensity ratio of EDS signals.

low temperatures $\left(300-400{ }^{\circ} \mathrm{C}\right)$ with a total pressure in the range $1-20$ Torr.

\subsection{Infiltration efficiency}

Infiltration efficiency was first studied on an assembly $(1 \mathrm{~cm}$ thick) constituted of 11 stacked tissues. Initial Thiele modulus was calculated for a first order reaction according to the formula proposed by Chang et al. [5]. When operating at 20 Torr and
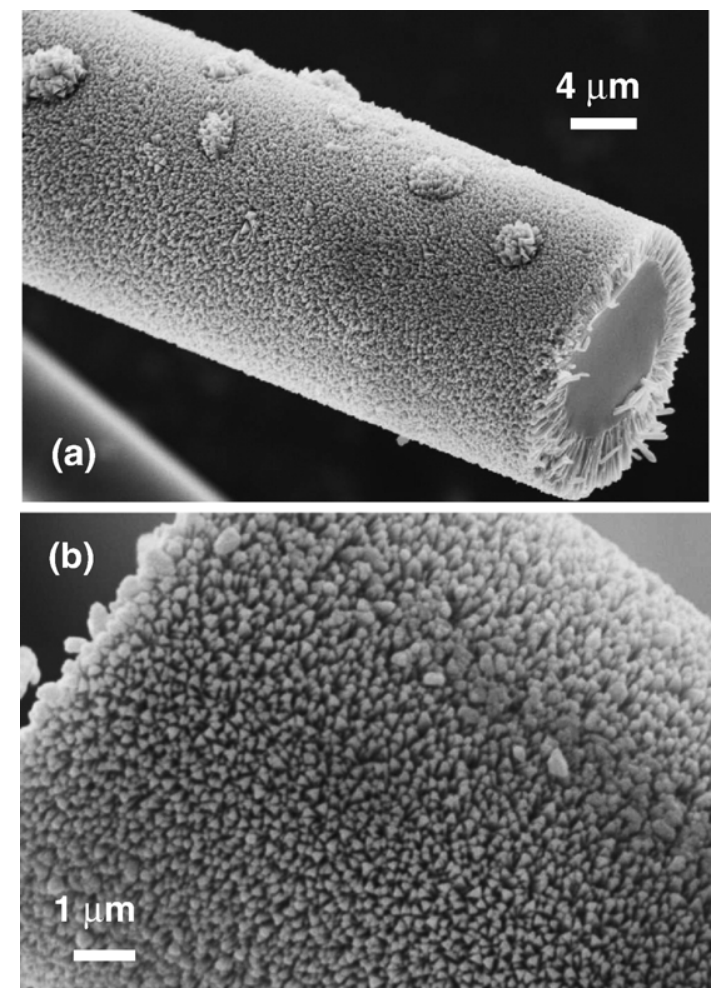

Fig. 4. Morphology of infiltrated $\mathrm{TiO}_{2}$ films on glass fibers. This columnar and porous morphology provides a relatively high specific surface area $\left(17 \mathrm{~m}^{2} \mathrm{~g}^{-1}\right)$ and is suitable for photocatalysis $\left(P=20\right.$ Torr, $T=400^{\circ} \mathrm{C}, \chi_{\text {TTIP }}=7.6 \times 10^{-5}$ or $26 \times 10^{-5}$ ). 
$400{ }^{\circ} \mathrm{C}\left(\chi_{\text {TTIP }}=26-124 \times 10^{-5}\right)$, infiltration was poor for the tissues in the middle of the stack. Decreasing the number of stacked tissues while keeping constant the pressure, did not improve the infiltration. By decreasing the pressure from 20 to 1 Torr, TTIP diffusion coefficient in $\mathrm{N}_{2}$ increased from 7.3 to $146 \mathrm{~cm}^{2} \mathrm{~s}^{-1}$ and as a result, $\mathrm{TiO}_{2}$ grew on the middle tissue too. At $400{ }^{\circ} \mathrm{C}\left(\chi_{\text {TTIP }}=5 \times 10^{-3}\right)$, infiltration is satisfactory but a thickness gradient along the $z$ axis is observed due to precursor depletion. The infiltration is more effective at $300{ }^{\circ} \mathrm{C}$ (Fig. 3). TTIP mole fraction plays an important role on infiltration efficiency. Indeed, at $300{ }^{\circ} \mathrm{C}$ and 1 Torr, infiltration is improved by increasing TTIP mole fraction. Infiltration efficiency is defined by the ratio between the Ti/Si EDS intensity ratio on the middle tissue and that on the external tissue for a given position along the $z$ axis $\left(16 \mathrm{~cm}\right.$ from reactor entrance). For $\chi_{\text {TTIP }}=26$, 124 and $500 \times 10^{-5}$, the infiltration efficiency raises from 0.05 to 0.25 and to $1( \pm 0.1)$, respectively. Tissue mass gain measurements of $\mathrm{TiO}_{2}$ are in agreement with these observations.

\subsection{Morphology and film microstructure}

Films obtained at $400{ }^{\circ} \mathrm{C}, 20$ Torr exhibit a columnar morphology (Fig. 4). A similar growth mode was previously observed on flat substrates $[9,12]$. Due to the surface curvature,
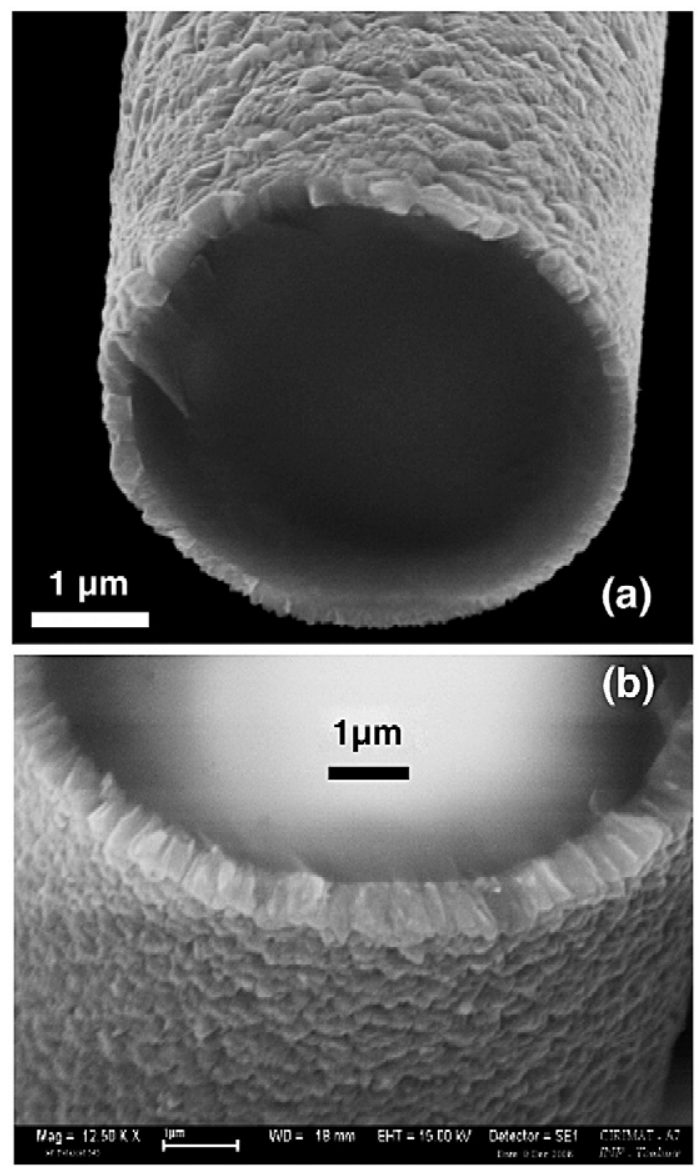

Fig. 5. Influence of the deposition temperature on the morphology of infiltrated $\mathrm{TiO}_{2}$ films on glass fibers using: (a) $P=1$ Torr, $T=300{ }^{\circ} \mathrm{C}, \chi_{\mathrm{TTIP}}=10^{-3}$ or $5 \times 10^{-3}$; (b) $P=1$ Torr, $T=400{ }^{\circ} \mathrm{C}, \chi_{\mathrm{TTIP}}=5 \times 10^{-3}$.

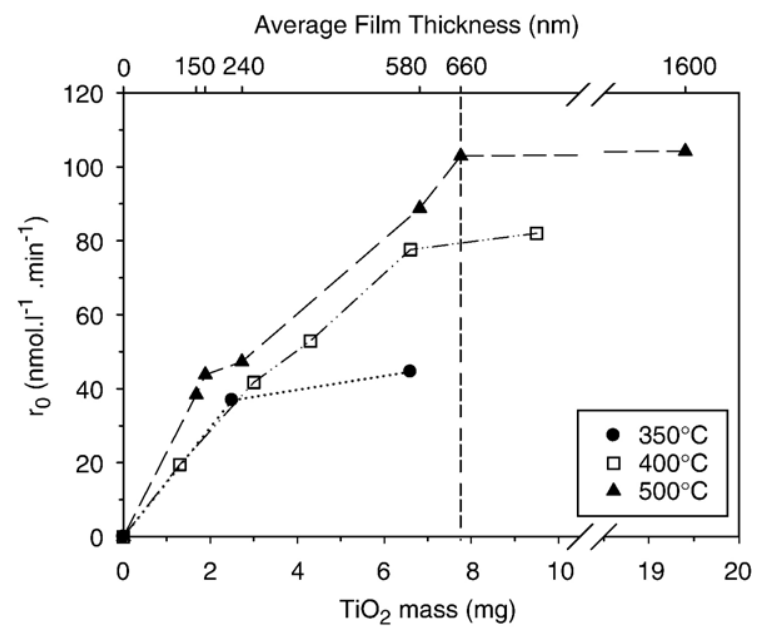

Fig. 6. Photocatalytic initial decomposition rate $r_{0}$ of Orange $\mathrm{G}$ aqueous solutions using single glass tissue uniformly coated with $\mathrm{TiO}_{2}$ thin films of various average thicknesses (mass of photocatalyst) and grown at different temperatures $\left(\chi_{\mathrm{TTIP}}=7.6 \times 10^{-5}\right.$ and $26 \times 10^{-5} ; P=20$ Torr; sample size $\left.20 \times 32 \times 1 \mathrm{~mm}^{3}\right)$.

the spacing between the columns is larger on microfibers than on flat glass surfaces. Porosity was $40 \%$ for a $1.5 \mu \mathrm{m}$ thick film on flat glass [16]. The porosity of deposits on microfibers could not be measured at this stage but we may assume that it is higher than $40 \%$. The specific surface area of $1-3 \mu \mathrm{m}$ thick films on glass fibers was found equal to $17 \pm 0.1 \mathrm{~m}^{2} \mathrm{~g}^{-1}$. This particular morphology is beneficial for photocatalytic applications. However under these growth conditions the infiltration efficiency is low. For the best CVI parameters $\left(300{ }^{\circ} \mathrm{C}\right.$, 1 Torr), a good $\mathrm{TiO}_{2}$ coverage of the glass fibers was observed but the films exhibit a compact granular morphology constituted of grains with an average size of $250 \mathrm{~nm}$ (Fig. 5a). The corresponding surface area drops down to $1.0 \pm 0.1 \mathrm{~m}^{2} \mathrm{~g}^{-1}$. At the same pressure, the growth turns more columnar at $400{ }^{\circ} \mathrm{C}$ resulting in a higher porosity (Fig. 5b). These conditions could be a good compromise.

\subsection{Photocatalytic activity}

Fig. 6 shows the variation of the initial decomposition rate $r_{0}$ as a function of $\mathrm{TiO}_{2}$ deposited mass for different growth temperatures. The samples were prepared under 20 Torr using a low TTIP mole fraction $\left(7.6 \times 10^{-5}\right)$, except for the $1.6 \mu \mathrm{m}$ thick one that was grown with $\chi_{\text {TTIP }}=26 \times 10^{-5}$ (poorer infiltration conditions). The average film thickness was calculated assuming a total and uniform coverage of the microfibers by the $\mathrm{TiO}_{2}$ film. All films exhibit the anatase structure except those grown at $500{ }^{\circ} \mathrm{C}$ which contains traces of rutile. The initial decomposition rate $r_{0}$ increases almost linearly with film thickness up to a critical thickness of ca. $600 \mathrm{~nm}$ and then tends to a plateau. Previous work on flat glass substrates has shown that UV-A light absorption was saturated for film thickness of 1$1.5 \mu \mathrm{m}$ [16]. This critical thickness is significantly higher than the threshold at $600 \mathrm{~nm}$ observed for the photocatalytic activity of deposits on microfibers. Therefore, the photocatalytic reaction rate for the films on microfibers is not limited by 
Table 1

Comparison between CVI growth conditions and the main features of the samples consisting of a 3 -stacked glass tissue assembly $\left(20 \times 100 \times 3 \mathrm{~mm}^{3}\right)$

\begin{tabular}{|c|c|c|c|}
\hline Sample series & \# 1 & $\# 2$ & \# 3 \\
\hline Pressure (Torr) & 20 & 1 & 1 \\
\hline Temperature $\left({ }^{\circ} \mathrm{C}\right)$ & 400 & 300 & 400 \\
\hline TTIP mole fraction $\left(10^{-5}\right)$ & $7.6-26$ & $124-500$ & 500 \\
\hline Morphology (columnar, porosity) & +++ & + & ++ \\
\hline Axial thickness uniformity ${ }^{a}$ & +++ & +++ & ++ \\
\hline Infiltration $^{\mathrm{a}}$ & + & +++ & ++ \\
\hline Thiele modulus & 1.5 & 0.11 & 0.13 \\
\hline $\begin{array}{l}\text { Normalized photocatalytic activity } \\
\qquad\left(\mathrm{nmol} 1^{-1} \min ^{-1} \mathrm{mg}^{-1}\right)\end{array}$ & $5.2^{\mathrm{b}}$ & $56^{\mathrm{c}}$ & $9.8^{\mathrm{c}}$ \\
\hline
\end{tabular}

${ }^{\mathrm{a}}+++$ excellent; ++ good; + poor.

${ }^{\mathrm{b}}$ External (top) tissue.

${ }^{\mathrm{c}}$ Middle tissue.

light absorption. It is more dependent on the microstructural features (porosity) for comparable amounts of deposited photocatalyst.

Grown at $350{ }^{\circ} \mathrm{C}, \mathrm{TiO}_{2}$ films show a higher compactness resulting in lower photocatalytic efficiency. Films grown in the temperature range $400-500{ }^{\circ} \mathrm{C}$, consist of well formed, regular and sharp columns. Therefore, their porosity is very likely higher than that of $40 \%$ found on flat substrates [16]. They exhibit an enhanced photocatalytic activity compared to films grown at $350{ }^{\circ} \mathrm{C}$ (Fig. 6). The best behavior, observed at $500{ }^{\circ} \mathrm{C}$, is in good agreement with a previous work [17] and can be explained by better crystallization and lower carbon contamination. Preliminary photocatalytic tests have also been carried out in the gas phase by following the decomposition of toluene vapors in a recirculating batch reactor. The results are in agreement with the tests presented in this paper and will be discussed elsewhere in relation with a recent report [18].

\section{Concluding remarks}

Fair thickness uniformity was achieved along the reactor axis for three series of samples (Table 1). Thiele modulus, a convenient parameter to predict the quality of infiltration, decreases sharply when lowering the pressure from 20 to 1 Torr. Infiltration is more efficient by lowering the temperature at $300{ }^{\circ} \mathrm{C}$ but the ensuing compact, big-sized grain morphology (Fig. 5a) is less favorable to photocatalytic activity (Fig. 6). At $400{ }^{\circ} \mathrm{C}$ and 20 Torr, the growth mode is definitely columnar (Fig. 4). The resulting high porosity and specific surface area are suitable for photocatalytic properties. But these experimental conditions yield poor infiltration through the glass tissue. The photocatalytic activity was comparatively measured for the three series of samples by evaluating the initial decomposition rates of Orange $\mathrm{G}$, normalized by the mass of the deposited photocatalyst (Table 1). Sample 2 is the most active although the $\mathrm{TiO}_{2}$ film exhibits a rather compact and unfavorable morphology. This can be explained by the most efficient infiltration (good uniformity and conformal coverage), which leads to a higher active surface area (greater number of catalytic sites). Sample 3 exhibits intermediate characteristics and, as a result, an intermediate photocatalytic activity is observed indicating that the infiltration efficiency is a major factor. Further works are in progress to optimize this CVI process for a one step production of supported photocatalysts.

\section{Acknowledgements}

Authors thank B.W. Sheldon (Brown University, Providence) and N. Reuge (LGC, Toulouse) for fruitful discussions on CVI technique, J. M. Herrmann, C. Guillard and E. Puzenat (IRCELYON, Lyon) for collaboration and discussions on gas phase photocatalysis, D. Truyen (CIRIMAT, Toulouse) for B.E. $\mathrm{T}$ measurements.

\section{References}

[1] S.M. Gupte, J.A. Tsamopoulos, J. Electrochem. Soc. 136 (1989) 555.

[2] N. Popovska, D.A. Streitwieser, C. Xu, H. Gerhard, J. Eur. Ceram. Soc. 25 (2005) 829.

[3] G.L. Vignoles, F. Langlais, C. Descamps, A. Mouchon, H. Le Poche, N. Reuge, N. Bertrand, Surf. Coat. Technol. 188-189 (2004) 241.

[4] H.C. King, M.C. Renier, K.E. Ellzey, W.J. Lackey, Chem. Vap. Depos. 9 (2003) 59.

[5] H.C. Chang, T.F. Morse, B.W. Sheldon, J. Am. Ceram. Soc. 80 (1997) 1805.

[6] J.M. Agullo, F. Maury, R. Morancho, Thin Solid Films 209 (1992) 52.

[7] D. Robert, A. Piscopo, O. Heintz, J.V. Weber, Catal. Today 54 (1999) 291

[8] H. Okudera, Y. Yokogawa, Thin Solid Films 423 (2003) 119.

[9] F.-D. Duminica, F. Maury, F. Senocq, Surf. Coat. Technol. 188189 (2004) 255.

[10] F.-D. Duminica, F. Maury, R. Hausbrand. Surf. Coat. Technol. (2007-this volume) http://dx.doi.org/10.1016/j.surfcoat.2007.04.011.

[11] F.-D. Duminica, F. Maury, R. Hausbrand. Surf. Coat. Technol. http://dx doi.org/10.1016/j.surfcoat.2007.04.061.

[12] C. Sarantopoulos, F.D. Duminica, A.N. Gleizes, F. Maury, in: A. Devi, H. Parala, M.L. Hitchman, R.A. Fischer, M.D. Allendorf (Eds.), Chem. Vap. Deposition XV, EUROCVD 15, Proc. volume PV 09, Electrochem. Soc., Pennington, NJ, 2005, p. 252.

[13] C.J. Taylor, D.C. Gilmer, D.G. Colombo, G.D. Wilk, S.A. Campbell, J. Roberts, W.L. Gladfelter, J. Am. Chem. Soc. 121 (1999) 5220.

[14] K.L. Siefering, G.L. Griffin, J. Electrochem. Soc. 137 (1990) 814.

[15] G.A. Battiston, R. Gerbasi, M. Porchia, L. Rizzo, Chem. Vap. Depos. 5 (1999) 73

[16] C. Sarantopoulos, A.N. Gleizes, F. Maury, E. Puzenat, C Guillard, J.-M Herrmann, Chem. Vap. Deposition (submitted for publication).

[17] S.-C. Jung, B.-H. Kim, S.-J. Kim, N. Imaishi, Y.-I. Cho, Chem. Vap. Depos. 11 (2005) 137.

[18] S.B. Kim, S.C. Hong, Appl. Catal., B 35 (2002) 305. 